\title{
ENZYME-ENHANCED EXTRACTION OF CAMPTOTHECIN AND ITS ANTICANCER ACTIVITY ON BREAST CANCER CELL LINE
}

\author{
SUJATHA NATARAJAN, SANGILIMUTHU ALAGAR YADAV* \\ Department of Biotechnology, Karpagam Academy of Higher Education, Coimbatore - 641 021, Tamil Nadu, India. \\ E-mail: smuthu.al@gmail.com
}

Received: 31 March 2018, Revised and Accepted: 26 April 2018

\section{ABSTRACT}

Objective: Camptothecin (CPT) is an alkaloid produced by endophytic fungi, and it acts against colon, uterine, and lung cancers as drug. Macerating enzyme cellulase is used to increase the extraction yield of CPT. The cytotoxicity and anticancer activity of CPT are being studied to aid in discovering its beneficial properties and its use as a lead compound in pharmacological industries.

Methods: In this work, the extraction of CPT from the endophytic fungi is enhanced using the crude enzyme cellulase obtained from Aspergillus niger. CPT was extracted from A. niger by two ways such as using macerating enzyme cellulase (CWME) and without macerating enzyme (CWOME). Highperformance liquid chromatography (HPLC) was carried out to characterize the extracted CPT against standard CPT. The yields of CPT extracted both ways were compared. Cytotoxicity of the extracted CPTs was studied against Vero cells. The anticancer activity of CPT was tested against the breast cancer cell line (MCF7).

Results: The extracted compound was confirmed to be CPT using HPLC. The yield of CPT extracted with enzyme was more than that extracted without enzyme. The extracted CPT was found to be safe up to $1000 \mu \mathrm{g} / \mathrm{ml}$ against Vero cells. The $\mathrm{IC}_{50}$ value of the CWME was found to be $62.5 \mu \mathrm{g} / \mathrm{ml}$ compared to the CWOME ( $\mathrm{IC}_{50} 125 \mu \mathrm{g} / \mathrm{ml}$ ) against the MCF7 cell line, thus inferring that the anticancer activity of CWME was higher than that of CWOME.

Conclusion: Thus, it can be concluded that cellulase helps to increase the extraction yield of CPT from A. niger. CPT is safe against normal cell line and exhibits anticancer properties against MCF7.

Key words: Camptothecin, Cellulase, Aspergillus niger, Breast cancer, Extraction, Enzyme maceration.

(c) 2018 The Authors. Published by Innovare Academic Sciences Pvt Ltd. This is an open access article under the CC BY license (http://creativecommons. org/licenses/by/4. 0/) DOI: http://dx.doi.org/10.22159/ajpcr.2018.v11i8.26333

\section{INTRODUCTION}

Secondary metabolites obtained from natural resources such as plants, animals, and microorganisms have served medicinal purposes by curing pain and suffering [1]. Even though natural resources are being used, many plant-associated microbes and their metabolites' uses are still unexplored. Microbes are major source for the production of natural drugs and to cure various diseases like cancer [2]. The endophytes offer a tremendous promise in the discovery of plant-associated secondary metabolites, their analogs, and novel lead compounds with therapeutic value. Endophytic fungi are known to produce a phelothra of anticancerous compounds [3]. The relationship between undiscovered biodiversity and novel chemistry [4] should be probed on a massive scale to facilitate sustained natural product drug discovery.

Camptothecin (CPT) is a modified pentacyclic alkaloid which is active in its closed E-ring (lactone) form to cause DNA damage and results in apoptosis. It is produced by some plants (angiosperms) [5]. It is also produced by an endophytic fungus that lives within the plants. CPT was first isolated by Monroe E. Wall and Mansukh C. Wani in 1958 from the extracts of the plant Camptotheca acuminate. CPT is a potent antitumor monoterpene indole alkaloid that predominantly targets cellular type I DNA topoisomerase (topo I). It binds to the enzyme and the DNA through hydrogen bonds and is selectively cytotoxic to the cells that replicate during the $S$ phase. The enzyme topoisomerases are attractive drug targets in cancer therapy. In the mid-1980s, this finding was a quantum leap that revitalized the interest in the drug. It is used to treat recurrent colorectal, ovarian, and lung cancer [6]. The enzyme has characteristics of high catalytic efficiency, strong specificity, etc. It is being used in industries to improve productiveness and ease the extraction process [7].
In the extraction process, the cellulase enzyme spreads to the extraction medium by its overwhelming capacity to pass through the obstacles of cell wall and intercellular substance. The commonly used enzyme, cellulase, contains more beneficial aspects, and also, it is used in traditional chinese medicine to cure various illnesses. Cellulases act as a macerating enzyme complex in the extraction and clarification of fruit and vegetable juices to increase the yield $[8,9]$.

In this study, the crude enzyme cellulase was extracted from Aspergillus niger. The crude cellulase enzyme was used for the extraction of CPT to obtain an increased yield from endophytic fungi [10]. The yield obtained was compared to the CPT extracted without cellulase enzyme. The novelty of this work arises from the fact that no previous work has been carried out to enhance the extraction of CPT using the cellulase enzyme (CWME). The anticancer potential of CWME was tested against normal and cancer cell line.

\section{METHODS}

Cellulase producing A. niger was obtained from Life Teck Research Centre, Chennai, Tamil Nadu. The plant specimen was authenticated by Prof. T. Jayaraman, Ph.D, Director, Plant Anatomy Research Centre, Medicinal Plant Research Unit, West Tambaram, Chennai. Cellulase enzyme was produced and purified [11,12]. The application of the enzyme thus produced has been used in this work.

\section{Extraction of CPT from endophytic fungi}

Fungal endophytes Aspergillus sp. were obtained from Life Teck Research Centre, Chennai, Tamil Nadu. For the production of CPT, spore suspensions of the culture were inoculated in Erlenmeyer flask $(500 \mathrm{ml})$ with SDA broth $(200 \mathrm{ml})$ enriched by $1 \%$ peptone and yeast 


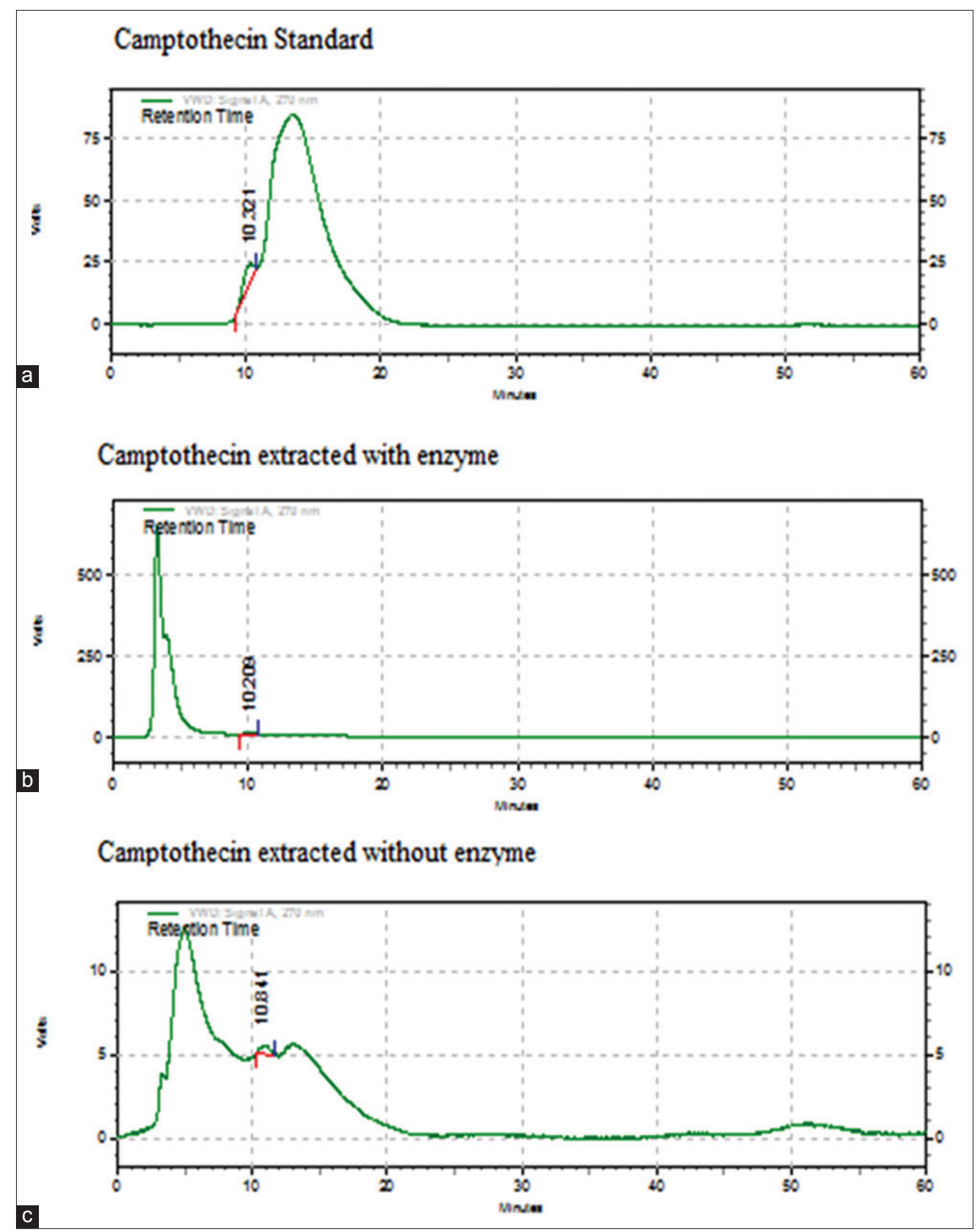

Fig. 1: High-performance liquid chromatography profile of (a) Camptothecin standard with retention time 10.321, (b) CWME with retention time 10.203, (c) CWOME with retention time 10.841

extract. The cultures were incubated at $28^{\circ} \mathrm{C}$ for $96 \mathrm{~h}$ in a rotary shaker (220 rpm) [13]. After the incubation period of $96 \mathrm{~h}$, the fully grown mycelia were harvested. By filtration, the mycelia and broth were separated. The mycelia obtained were homogenized after thorough washing with sterile distilled water. The homogenized broth was treated with $50 \mathrm{ml}$ sodium acetate buffer (pH 5). $0.3 \mathrm{ml}$ of cellulase (0.054 UI) was added and the mixture was exposed to continuous stirring process with magnetic stirrer for $24 \mathrm{~h}$ at $37^{\circ} \mathrm{C}$. This extraction was carried out with cellulase enzyme and without cellulase enzyme separately. The resulting homogenate was extracted with equal volume of chloroform:methanol $(4: 1 \mathrm{v} / \mathrm{v})$ solvent mixture. The residue was obtained after stripping off the solvent [14]. The crude CPT obtained was subjected to qualitative high-performance liquid chromatography (HPLC) with standard CPT (Sigma-Aldrich Inc.) for the detection of CPT.

In vitro cytotoxicity against normal and cancer cell lines [15]

Two selected cell lines, VERO and MCF-7 breast cancer cell lines, were grown on 24 -well tissue culture plates and incubated at $37^{\circ} \mathrm{C}$ with $5 \%$ $\mathrm{CO}_{2}$ condition for $48 \mathrm{~h}$. After the cell reaches the confluence, incubation was continued for another $24 \mathrm{~h}$ after addition of the samples such as Standard CPT, CWME, and CWOME into each well except control. After incubation, the sample was removed from the well and washed with phosphate-buffered saline ( $\mathrm{pH} 7.4) .100 \mu \mathrm{l} /$ well $(5 \mathrm{mg} / \mathrm{ml})$ of $0.5 \%$ of 3-(4, 5-dimethyl-2-thiazolyl)-2, 5-diphenyl--tetrazolium bromide was added and incubated for $4 \mathrm{~h}$. After incubation, $1 \mathrm{ml}$ of DMSO was added in all the wells. The absorbances of treated and non-treated cultures were observed at $570 \mathrm{~nm}$ using ultraviolet-visible spectrophotometer with DMSO serving as blank. Measurements were performed and the concentration required for a $50 \%$ inhibition $\left(\mathrm{IC}_{50}\right.$ ) was determined. The $\%$ cell viability was calculated using the following formula:

$\%$ cell viability $=$ OD value of treated cells $/ O D$ value of control cells $\times$ 100 .

\section{RESULTS AND DISCUSSION}

\section{Extraction of CPT}

The CPT extracted from A. niger was characterized. The extraction of CPT was carried out in two ways: Using macerating enzyme cellulase 


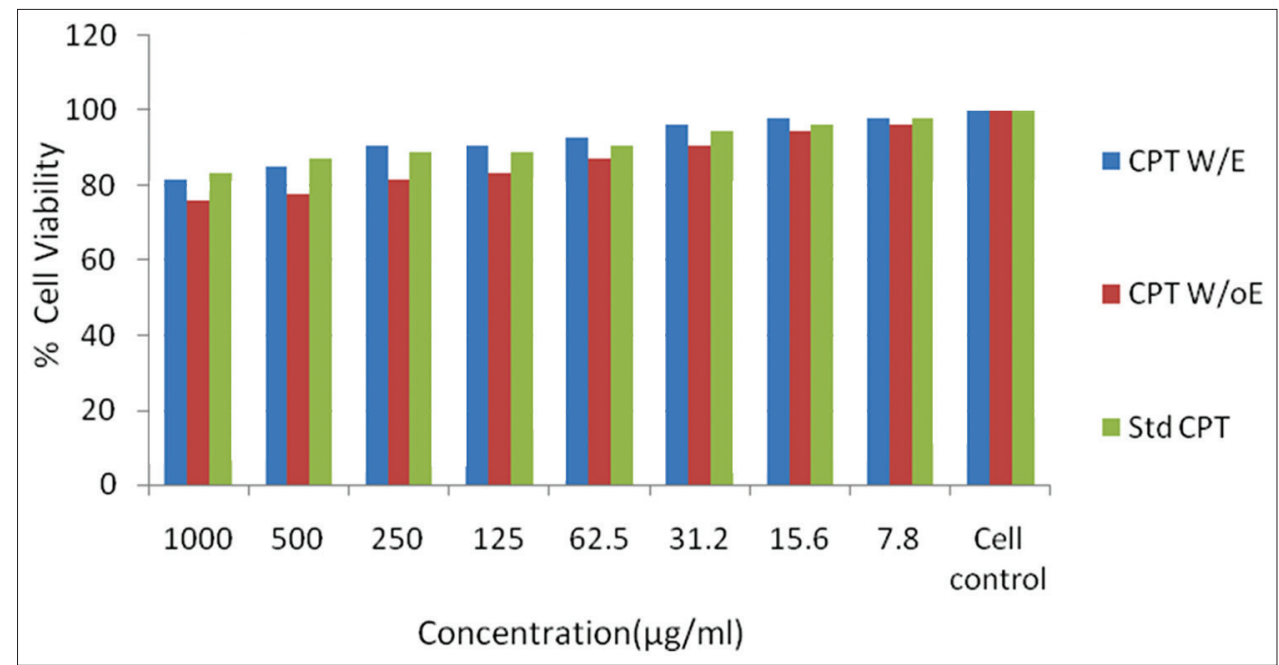

Fig. 2. Cytotoxicity effect of camptothecin standard, CWME, and CWOME on VERO cells
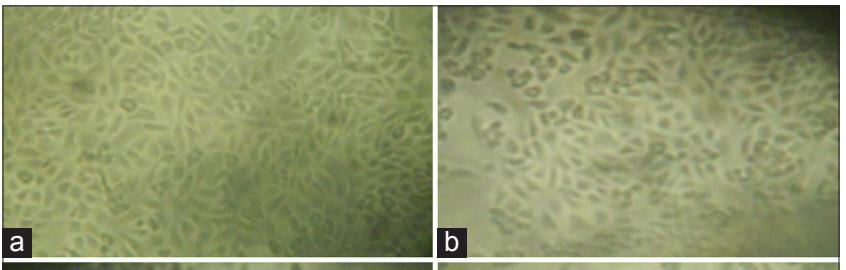

c

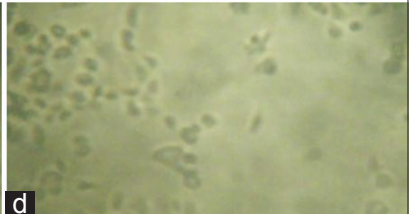

Fig. 3: Cytotoxicity effect of camptothecin standard on Vero cell line, cells are imaged at $\times 20$ magnification (scale bar, $100 \mu \mathrm{M}$ ). (a) Control, (b) Toxicity at $7.8 \mu \mathrm{g} / \mathrm{ml}$, (c) Toxicity at $62.5 \mu \mathrm{g} / \mathrm{ml}$, (d) Toxicity at $1000 \mu \mathrm{g} / \mathrm{ml}$

and without macerating enzyme cellulase. The extracted CPT was screened with HPLC against standard CPT for quantification of the yield and the observation of their retention times. The yield of CPT extracted with enzyme was $0.5512 \mathrm{mg} / \mathrm{L}$ and CPT without enzyme was $0.175 \mathrm{mg} / \mathrm{L}$. The yield of CPT extracted with enzyme was more than that extracted without enzyme (Fig. 1).

Singh et al. [16] analyzed CPT on the basis of HPLC and found similar conclusions. Patil et al. [17] confirmed the amount of CPT present in each sample using HPLC. Similar analysis has been carried out in this study. In the HPLC analysis carried out in this study, the retention time of CPT standard was found to be $10.321 \mathrm{~min}$. The CWME was confirmed to be CPT as the retention time was recorded to be 10.209 min while that of CWOME was $10.841 \mathrm{~min}$. As the retention time was very close to that of the standard, the purity of the compound isolated can be affirmed. There have been no previous efforts to enhance the extraction of CPT using enzyme. This work is the first record of enzyme-assisted enhanced extraction of CPT from endophyic fungi $A$. niger. Saito et al. [18] described the use of Diaion HP-20 a polystyrene resin to the medium to reversibly absorb CPT produced and partially secreted by hairy root cultures of Ophiorrhiza pumila, which can later be easily recovered from the medium. However, due to the shortage of natural resources and subsequent environmental concerns, extraction from plants is problematic. Thus, alternative and more sustainable methods for CPT production are required.

\section{In vitro cytotoxicity against normal and cancer cell lines}

The biological activity of standard CPT and CPT extracted with CWME and without enzyme CWOME were tested against normal (VERO) and breast cancer (MCF-7) cell lines which resulted in comparable activities (Figs. 1 and 2).

The cytotoxicity of CPT Standard, CWME, and CWOME on VERO cell was determined. Figs. 2 and 3 depict the cytotoxic effect of CPT standard, CWME, and CWOME against the Vero cells. Varying concentration of the samples was plotted against the percentage cell viability. The difference in the cell population can be observed in Fig. 3. Figs. 2 and 3 show that the growth of VERO cell was significantly unhampered in comparison with the control cells. The samples when interacting with the cells do not change the viability of the VERO cell line. Hence, it is safe against the normal cells even up to $1000 \mu \mathrm{g} / \mathrm{ml}$.

The cytotoxicity of samples on MCF-7 cells was determined. Figs 4-6 depict the anticancer activity of CPT standard, CWME, and CWOME against the MCF-7 cells. Varying concentration of the samples was plotted against the percentage cell viability. The difference in cell population at various concentrations of the samples can be clearly observed in Figs. 5 and 6. Figs. 4-6 show that the growth of MCF-7 cell was significantly inhibited as compared to the control in dosedependent manner. The $\mathrm{IC}_{50}$ value of standard CPT against MCF-7 at $24 \mathrm{~h}$ incubation was estimated as $15.6 \mu \mathrm{g} / \mathrm{ml}$ (Fig. 7).

CPT is a kind of phytocompound with anticancer potential. It has a better effect on the cancer of gastrointestinal tract. It was discovered recently that CPT could be transformed into 10 -hydroxy CPT in vitro by enzymatic method providing a new way to solve the resource issue of 10-hydroxy CPT [19].

The $\mathrm{IC}_{50}$ value of CWME against MCF-7 cell line at $24 \mathrm{~h}$ incubation was estimated and found to be $62.5 \mu \mathrm{g} / \mathrm{ml}$, but CWOME was found to be $125 \mu \mathrm{g} / \mathrm{ml}$. When compared with standard CPT, CWME showed higher percentage of inhibition than CWOME. Chu et al. [20] observed DNA damage in MCF-7 cells treated with CPT6. Low-dose CPT6 causes cell nucleus fragmentation and DNA damage. It could inhibit proliferation and induce apoptosis in MCF-7 cells due to its significant cytotoxic effect. Thus, CPT 6 appears to unveil its potent antitumor activity against human breast tumor MCF-7 cells by means of inducing apoptosis, proving to be a useful alternative drug for breast cancer therapy [20]. CPT may be used as antiproliferative drug for cancer cells, but the goal of oncologists of chemotherapy is to minimize damage to normal cells and to enhance antiproliferative effect on cancer cells. 


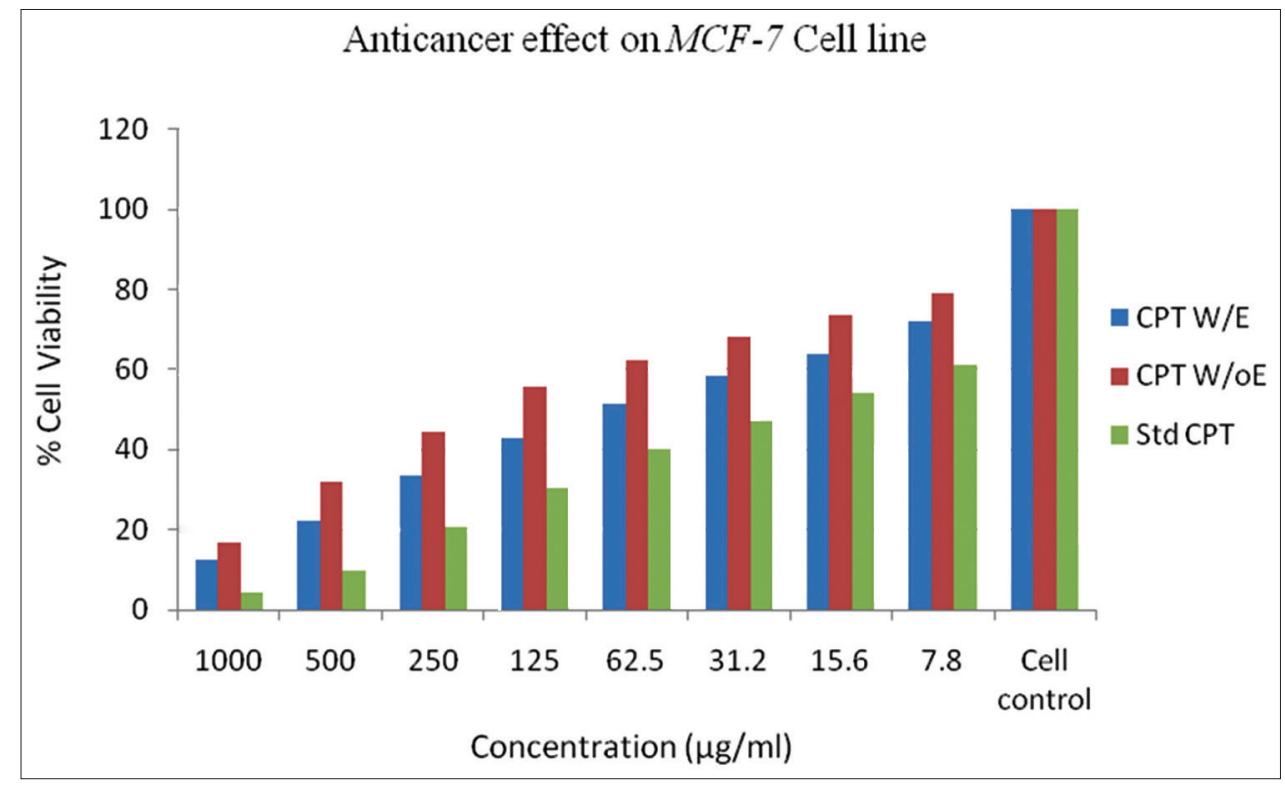

Fig. 4: Cytotoxicity effect of camptothecin standard, CWME, and CWOME on MCF-7 cells

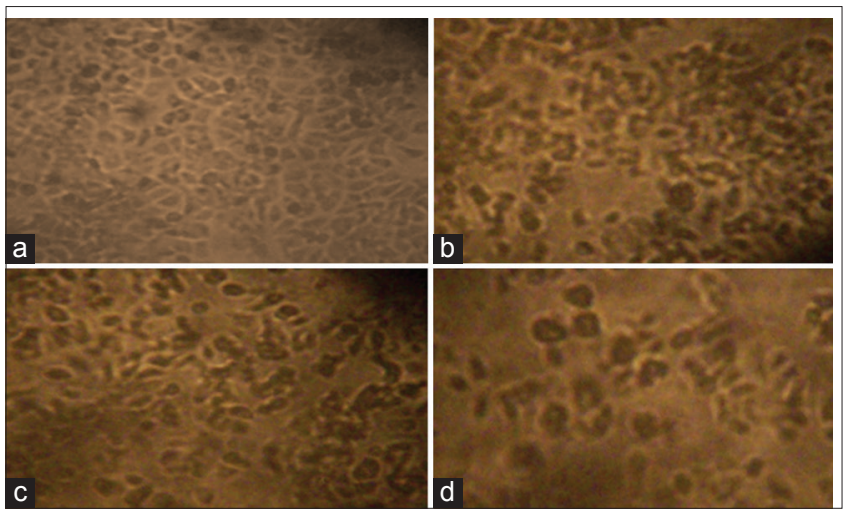

Fig. 5: Anticancer effect of CWME on MCF 7 cell line. Cells are imaged at $\times 20$ magnification (scale bar, $100 \mu \mathrm{M}$ ). (a) Control, (b) Toxicity at $7.8 \mu \mathrm{g} / \mathrm{ml}$, (c) Toxicity at $15.6 \mu \mathrm{g} / \mathrm{ml}$, (d) Toxicity at $1000 \mu \mathrm{g} / \mathrm{ml}$
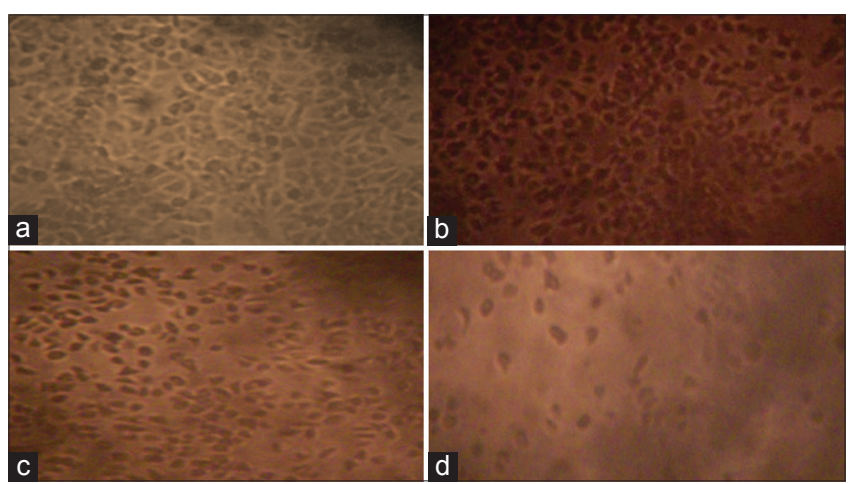

Fig. 6: Anticancer effect of CWOME on MCF 7 cell line. Cells are imaged at $\times 20$ magnification (scale bar, $100 \mu \mathrm{M}$ ). (a) Control, (b) Toxicity at $7.8 \mu \mathrm{g} / \mathrm{ml}$, (c) Toxicity at $62.5 \mu \mathrm{g} / \mathrm{ml}$, (d) Toxicity at $1000 \mu \mathrm{g} / \mathrm{ml}$

\section{CONCLUSION}

In a first of its kind attempt, CPT extraction was enhanced with the use of the cellulase enzyme. CPT was extracted from the endophytic fungi $A$.
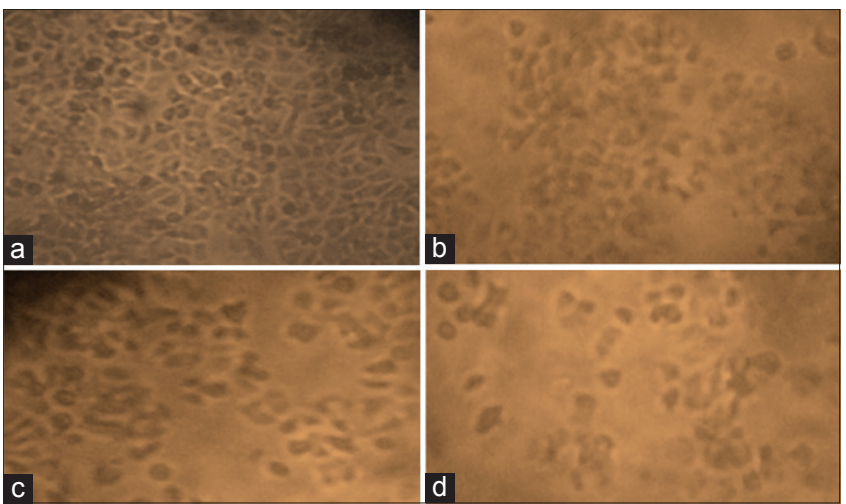

Fig. 7: Anticancer effect of standard camptothecin on MCF 7 cell line, Cells are imaged at $\times 20$ magnification (scale bar, $100 \mu \mathrm{M}$ ). (a) Control, (b) Toxicity at $7.8 \mu \mathrm{g} / \mathrm{ml}$, (c) Toxicity at $125 \mu \mathrm{g} / \mathrm{ml}$,

(d) Toxicity at $1000 \mu \mathrm{g} / \mathrm{ml}$

niger with and without the use of enzyme cellulase. It was characterized and quantified using HPLC. Parallel to the enhancement of the release yield, enzyme-induced extraction prevents the use of high quantities of organic solvents and serves as a cost-effective method of extraction. The anticancer activity of CWME and CWOME was analyzed against the breast cancer cell line MCF7. The cytotoxicity of the extracts CWME and CWOME was tested against Vero cells. The cytotoxicity studies of CWME and CWOME showed higher percentage inhibition against MCF 7 ( $\left.\mathrm{IC}_{50}\right)$, and it was safe with VERO cell line. The CWME showed better inhibition level on breast cancer cell line. Thus, it can be concluded that the enhanced extraction of CPT using the macerating enzyme cellulase, not only improved its yield but also its quality. In addition, the immense anticancer potential of CPT can be used to explore its role in anticancer drugs.

\section{ACKNOWLEDGMENTS}

The authors gratefully acknowledge the authorities of Karpagam Academy of Higher Education for financial assistance and necessary facilities to carry out this research work.

\section{CONFLICTS OF INTEREST}

The authors have no conflicts of interest. The manuscript is developed by the joint efforts and contributions of the authors. 


\section{REFERENCES}

1. Demain AL. From natural products discovery to commercialization: A success story. J Ind Microbiol Biotechnol 2006;33:486-95.

2. Newman DJ. Microbial prescreens for anticancer activity. SIM News 2008;58:132-50

3. Anand DF, Rajesh KT. Endophytic fungi: Treasure for anti-cancerous compounds. Int J Pharm Pharm Sci 2016;8:35-42.

4. Smith SA, Tank DC, Boulanger LA, Bascom-Slack CA, Eisenman K, Kingery D, et al. Bioactive endophytes warrant intensified exploration and conservation. PLoS One 2008;3:e3052.

5. Wall ME, Wani MC. Camptothecin and taxol: From discovery to clinic. J Ethnopharmacol 1996;51:239-53.

6. Amna T, Puri SC, Verma V, Sharma JP, Khajuria RK, Musarrat J, et al. Bioreactor studies on the endophytic fungus Entrophospora infrequens for the production of an anticancer alkaloid camptothecin. Can J Microbiol 2006;52:189-96.

7. Panke S, Wubbolts MG. Enzyme technology and bioprocess engineering. Curr Opin Biotechnol 2002;13:111-6.

8. Minussi RC, Pastore GM, Durán N. Potential applications of laccase in the food industry. Trends Food Sci Technol 2002;13:205-16

9. De Carvalho LM, De Castro IM, Da Silva CA. A study of retention of sugars in the process of clarification of pineapple juice (Ananas comosus, L. Merril) by micro-and ultra-filtration. J Food Eng 2008;87:447-54

10. Sujatha N, Sanglimuthu AY, Sowmya PM. Influence of macerating enzyme-Cellulase on the extraction of valuable compounds: Carotenoid and Camptothecin. Int J Res Pharm Sci 2018;9:115-20.

11. Hurst PL, Nielsen J, Sullivan PA, Shepherd MG. Purification and properties of a cellulase from Aspergillus niger. Biochem $\mathrm{J}$ $1977 ; 165: 33-41$
12. Sujatha N, Seethalakshmi I. Production and optimization of Cellulase produced by Aspergillus species isolated from soil. Indian J Appl Microbiol 2013;16:85-91.

13. Pu X, Qu X, Chen F, Bao J, Zhang G, Luo Y, et al. Camptothecinproducing endophytic fungus Trichoderma atroviride LY357: Isolation, identification, and fermentation conditions optimization for camptothecin production. Appl Microbiol Biotechnol 2013;97:9365-75.

14. Wiedenfeld H, Furmanowa M, Roeder E, Guzewska J, Gustowski W. Camptothecin and 10-hydroxycamptothecin in callus and plantlets of Camptotheca acuminata. Plant Cell Tissue Organ Cult 1997;49:213-8.

15. Mosmann T. Rapid colorimetric assay for cellular growth and survival: Application to proliferation and cytotoxicity assays. J Immunol Methods 1983;65:55-63.

16. Singh I, Kumaravadivel N, Gnanam R, Vellaikumar S. RP-HPLC analysis for camptothecin content in Nothapodytes nimmoniana, an endangered medicinal plant. J Med Plants Res 2010;4:255-9.

17. Patil AS, Kale AS, Patil SR, Paikrao HM. Validation of accumulation of camptothecin content, an anti-cancer alkaloid in nothapodytes nimmoniana graham. in phenotypic variants: Method for identifying high-yielding sources of alkaloid. Int J Pharm Pharm Sci 2016;8:35-42.

18. Saito K, Sudo H, Yamazaki M, Koseki-Nakamura M, Kitajima M, Takayama $\mathrm{H}$, et al. Feasible production of camptothecin by hairy root culture of Ophiorrhiza pumila. Plant cell Rep 2001;20:267-71.

19. Yu BY. Biotransformation of nature active ingredient and development of innovative drug. Front Sci Technol Acad Rev 2010;21:36-9.

20. Chu C, Xu J, Cheng D, Li X, Tong S, Yan J, et al. Anti-proliferative and apoptosis-inducing effects of camptothecin-20 (s)-O-(2-pyrazolyl-1) acetic Ester in Human Breast Tumor MCF-7 Cells. Molecules 2014;19:4941-55. 